MaPan : Jurnal Matematika dan Pembelajaran

p-ISSN: 2354-6883 ; e-ISSN: 2581-172X

Volume 6, No 1, June 2018 (31-39)

DOI: https://doi.org/10.24252/mapan.2018v6n1a4

\title{
PROFIL KEMAMPUAN SPASIAL MAHASISWA CAMPER DALAM MEREKONSTRUKSI IRISAN PRISMA DITINJAU DARI PERBEDAAN GENDER
}

\author{
M. Imamuddin'1), Isnaniah'2) \\ 1,2Kampus 2 IAIN Bukittinggi \\ 1,2Jl. Gurun Aur Kubang Putih Agam Sumbar, Indonesia \\ E-mail: m.imamuddin76@yahoo.co.id ${ }^{1}$, iis_imam@yahoo.co.id²)
}

Submitted: 24-01-2018, Revised: 23-04-2018, Accepted: 02-05-2018

\begin{abstract}
Abstrak:
Penelitian ini bertujuan menggambarkan kemampuan mahasiswa camper dalam merekonstruksi irisan prisma ditinjau dari perbedaan gender. Subjek dalam penelitian ini diambil secara acak dua orang mahasiswa camper dengan jenis kelamin berbeda yaitu satu orang laki-laki dan satu orang perempuan. Hasil penelitian menyimpulkan kemampuan mahasiswa laki-laki dalam mengkonstruksi irisan prisma masih lemah dalam ketelitian dan daya abstraksinya khusunya kemampuan visualisasi keruangan (spatial visualisation), sedangkan kemampuan mahasiswa perempuan adalah lemah dalam kemampuan persepsi keruangan (spatial perception), lemah dalam kemampuan relasi keruangan (spatial relations) dan lemah dalam kemampuan visualisasi keruangan (spatial visualisation).
\end{abstract}

Kata Kunci: Kemampuan Spasial, Mahasiswa Camper, Irisan Prisma, Gender

\section{THE PROFILE OF CAMPER STUDENT ABILITY IN RECONSTRUCTING PRISM SLICES IN TERMS OF GENDER DIFFERENCES}

\begin{abstract}
:
This study aims to describe the profile of camper student ability in reconstructing prism slices in terms of gender differences. Subjects in this study are two camper students with different gender, male and female who were randomly taken. The result of the research concludes that the ability of male students in constructing prism slices is still weak in accuracy and abstraction power for spatial visualization ability, while other is weak in some aspects in spatial ability: perception, relations and visualization.
\end{abstract}

Keywords: Spatial Ability, Camper Students, Prism Slices, Gender

How to Cite: Imamuddin, M. \& Isnaniah. (2018). Profil Kemampuan Spasial Mahasiswa Camper dalam Merekonstruksi Irisan Prisma Ditinjau dari Perbedaan Gender. MaPan : Jurnal Matematika dan Pembelajaran, 6 (1), 31-39. 
G eometri menjadi salah satu materi yang wajib pada mata pelajaran matematika. Dari sekolah tingkat dasar sampai ke perguruan tinggi dalam belajar matematika, pelajar akan mendapatkan materi geometri. Di tingkat perguruan tinggi khususnya jurusan matematika ataupun pendidikan matematika, geometri merupakan matakuliah tersendiri yang wajib dipelajari oleh mahasiswa. Namun demikian, masih banyak mahasiswa calon guru matematika yang belum menguasai dengan baik dan benar materi geometri khususnya geometri analitik ruang. Khusus materi geometri, berdasarkan hasil survei dari Programme for International Student Assessment (PISA) 2000/2001 diperoleh bahwa siswa sangat lemah dalam memahami geometri, khususnya dalam pemahaman ruang dan bentuk (Soemadi, 1994). Agar dapat belajar geometri dengan baik dan benar, siswa dituntut untuk menguasai kemampuan dasar geometri, keterampilan dalam pembuktian, keterampilan dalam membuat lukisan dasar geometri dan mempunyai pandangan ruang yang memadai.

Berdasarkan sudut pandang psikologi, geometri merupakan penyajian abstraksi dari pengalaman visual dan spasial, misalnya bidang, pola, pengukuran dan pemetaan. Oleh karena itu jelas bahwa kemampuan spasial sangat berperan penting dalam pembelajaran tentang geometri (Kartono, 2012). Kemampuan spasial didefinisikan sebagai kemampuan untuk membangkitkan, mempertahankan, mendapat kembali dan mengubah bayangan visual (Lohman, 1993). Sejalan dengan hal tersebut, Linn \& Petersen dalam (Yilmaz, 2009), dan Asis dkk, (2015) mengemukakan bahwa kemampuan spasial menyangkut kemampuan dalam merepresentasi, mentransformasi, dan memanggil kembali informasi simbolis.

Maier (Isnaniah, 2016) membagi unsur-unsur kemampuan spasial sebagai berikut: (1) spatial perception (persepsi keruangan). Persepsi keruangan merupakan kemampuan mengamati suatu bangun ruang atau bagian-bagian ruang yang diletakkan posisi horizontal atau vertical, (2) spatial visualisation (visualisasi keruangan). Visualisasi keruangan sebagai kemampuan untuk membayangkan atau membayangkan gambar tentang suatu bangun ruang yang bagian-bagian terdapat perubahan atau perpindahan. (3) mental rotation (rotasi pikiran). Rotasi pikiran mencakup kemampuan merotasikan suatu bangun ruang secara cepat dan tepat. (4) spatial relations (relasi keruangan). Kemampuan untuk mengerti wujud keruangan dari suatu benda atau bagian dari benda dan hubungannya antara bagian yang satu dengan yang lainnya. (5) spatial orientation (orientasi keruangan). Kemampuan untuk mencari 
pedoman sendiri secara fisik atau mental di dalam ruang, atau berorientasi dalam situasi keruangan yang istimewa.

Selain kemampuan spasial, kecerdasan seseorang/mahasiswa merupakan salah satu faktor yang dapat menentukan berhasil atau tidaknya dalam belajar matematika khususnya materi geometri. Salah satu kemampuan/kecerdasan itu adalah kecerdasan dalam mengatasi masalah/adversity quotient. Adversity Quotient (AQ) adalah kecerdasan mengatasi masalah (daya juang), yaitu kecerdasan seseorang dalam menghadapi kesulitan yang menghadangnya. (Stoltz, 2000) mengelompokkan orang ke dalam tiga kategori $A Q$, yaitu: quitter ( $A Q$ rendah), camper ( $A Q$ sedang), dan climber ( $A Q$ tinggi).

Mahasiswa quitter hanya menerima pembelajaran ataupun tugas-tugas yang diberikan oleh guru dan mengerjakannya dengan motivasi yang rendah, sedangkan mahasiswa camper, prestasi mereka tidak tinggi dan kontribusinya tidak besar juga. Mahasiswa climber prestasinya tinggi dan kontribusinya besar. Selanjutnya dalam tulisan ini mahasiswa dengan kemampuan rendah disebut mahasiswa quitter, mahasiswa dengan kemampuan sedang disebut mahasiswa camper dan mahasiswa dengan kemampuan tinggi disebut mahasiswa climber.

Terkait dengan kemampuan spasial, setiap mahasiswa memiliki kemampuan spasial yang berbeda-beda. Perbedaan yang paling sering dikemukakan adalah terkait laki-laki dan perempuan atau perbedaan gender, baik yang disebabkan oleh factor biologis maupun proses social dan cultural (Nazaruddin, 2015). Menurut Maccoby \& Jacklyn (1974) mengatakan laki-laki dan perempuan mempunyai perbedaan kemampuan antara lain sebagai berikut: perempuan mempunyai kemampuan verbal lebih tinggi daripada laki-laki, laki-laki lebih unggul dalam kemampuan visual spatial (penglihatan keruangan) daripada perempuan, laki-laki lebih unggul dalam kemampuan matematika.

Menurut (Susento, 2006) perbedaan gender bukan hanya berakibat pada perbedaan kemampuan dalam matematika, tetapi cara memperoleh pengetahuan matematika juga terkait dengan perbedaan gender.

Penelitian ini bertujuan untuk menggambarkan profil kemampuan spasial mahasiswa calon guru matematika dengan tingkat kemapuan sedang (mahasiswa camper) dalam merekonstruksi irisan prisma ditinjau dari perbedaan gender. 


\section{METODE PENELITIAN}

Penelitian ini merupakan penelitian deskriptif dengan pendekatan kualitatif. Penelitian ini bertujuan menggambarkan profil kemampuan mahasiswa camper dalam merekonstruksi irisan prisma ditinjau dari perbedaan gender.

Subjek dalam penelitian ini adalah mahasiswa calon guru matematika IAIN Bukittinggi yang telah menempuh mata kuliah geometri bidang dan ruang. Subjek dalam penelitian ini, ditentukan dengan cara acak terhadap dua orang mahasiswa camper (mahasiswa berkemampuan sedang) dengan jenis kelamin yang berbeda. Satu orang laki-laki dan satu orang perempuan yang selanjutnya disebut subjek L (untuk laki-laki) dan Subjek P (untuk perempuan).

Instrumen utama dalam penelitian ini adalah peneliti sendiri. Fungsi peneliti sebagai pengumpul data pada penelitian ini tidak bisa digantikan oleh orang lain. Selain itu, instrumen yang digunakan dalam penelitian ini adalah Lembar Tugas Mahasiswa (LTM) yang berisikan soal tentang irisan prisma. Soal yang digunakan dalam penelitian ini adalah sebagai berikut: "Kubus ABCD.EFGH dengan panjang rusuk 6 satuan, sudut sudut $60^{\circ}$, perbandingan proyeksi 2 : 1 dan sebagai bidang frontal CDHG. Pada kubus tersebut terdapat titik $\mathrm{P}, \mathrm{Q}$ dan $\mathrm{R}$. Titik $\mathrm{P}$ terletak pada rusuk $\mathrm{CG}(\mathrm{P}=2 / 6 \overline{C G})$, titik $\mathrm{Q}$ terletak pada rusuk $\mathrm{DH}(\mathrm{Q}=1 / 6 \overline{D H})$, dan titik $\mathrm{R}$ terletak pada rusuk $\mathrm{AE}(\mathrm{R}=4 / 6 \overline{A E})$. Gambarlah irisan prisma ABCD.EFGH yang melalui titik $\mathrm{P}, \mathrm{Q}$ dan $\mathrm{R}$ dengan menggunakan cara sumbu afinitas"

Pengumpulan data dilakukan dengan cara memberikan Lembar Tugas Mahasiswa (LTM) kepada subjek L dan P. Berdasarkan hasil jawaban subjek L dan $\mathrm{P}$ selanjutnya dilakukan wawancara yang mendalam. Analisis data dilakukan dengan cara membandingkan hasil kerja atau jawaban subjek L dan $\mathrm{P}$ terhadap soal yang terdapat pada LTM dengan informasi yang diperoleh pada saat wawancara dengan subjek L dan P. Kesimpulan dibuat dengan cara mencocokkan atau mencari kesamaannya dengan tahapan atau langkahlangkah dari menggambar irisan prisma.

\section{HASIL DAN PEMBAHASAN}

Dari hasil penelitian diperoleh jawaban/hasil kerja maupun hasil wawancara dari subjek $\mathrm{L}$ dan $\mathrm{P}$ terkait permasalahan yang diberikan. Berdasarkan hasil kerja dan wawancara dilanjutkan dengan menganalisis dengan mencari kesamaannya. Adapun hasilnya sebagai berikut: 


\section{Subjek L}

Hasil kerja subjek L terkait permasalahan yang diberikan dapat dilihat pada gambar 1 .

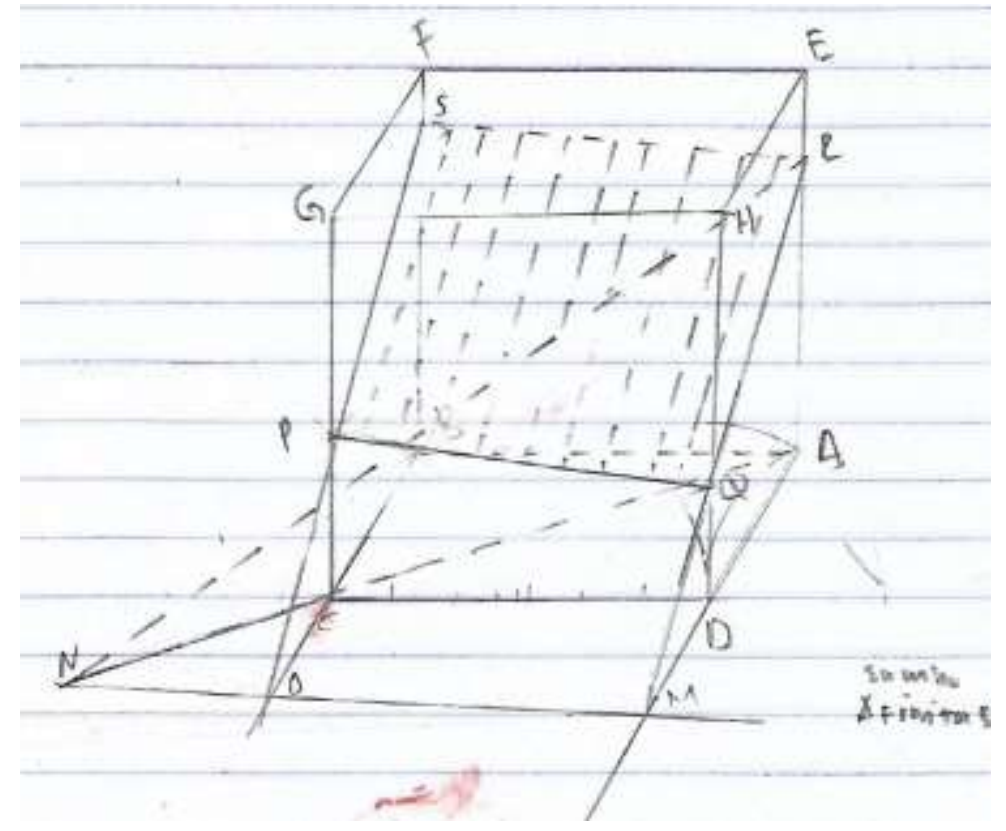

Gambar 1. Irisan Prisma yang Dibuat Subjek L

Berdasarkan gambar yang dibuat oleh subjek L tersebut, dilanjutkan dengan wawancara yang mendalam, diperoleh informasi bahwa subjek L sudah benar menentukan letak titik $\mathrm{P}$ pada rusuk $\overline{C G}$ dan menentukan letak titik $\mathrm{Q}$ pada rusuk $\overline{D H}$ tetapi kurang akurat/sempurna. Berdasarkan hasil wawancara diperoleh informasi bahwa subjek L dalam menggambar prisma tidak mendahului dengan perencanaan yang matang (tidak membuat perencanaan gambar). Hal ini menyebabkan subjek L tidak mempunyai perhitungan yang akurat dalam membagi panjang setiap rusuk pada limas ABCD.EFGH, sehingga dalam menempatkan titik $\mathrm{P}$ dan $\mathrm{Q}$ tidak teliti $(\mathrm{P} \neq 2 / 6$ $\overline{C G}$ dan $\mathrm{Q} \neq 1 / 6 \overline{D H})$.

Selain itu dalam membuat garis $\overleftrightarrow{R P}$, subjek L membuatnya atau menggambarnya tidak melalui titik $\mathrm{P}$ artinya gambarnya kurang benar/akurat/teliti. Hal ini menandakan subjek $\mathrm{L}$ belum terampil dalam membuat/menggambar garis yang menghubungkan dua titik. Dan yang terakhir subjek L membuat garis $\overline{O P}$ tidak sempurna, dimana $\overline{P S}$ di buat tidak putus-putus dan $\overline{B C}$ dibuat dengan garis tidak putus-putus, seharusnya $\overline{P S}$ dan $\overline{B C}$ dibuat putus-putus yang menandakan letak $\overline{P S}$ dan $\overline{B C}$ berada dibagian yang tidak terlihat dari depan. Berdasarkan wawancara dengan 
subjek L diperoleh informasi, bahwa subjek L masih lemah dalam daya abstraksinya khususnya dalam kemampuan visualisasi keruangan (Spatial visualisation).

\section{Subjek P}

Hasil kerja subjek $\mathrm{P}$ terkait permasalahan yang diberikan dapat dilihat pada gambar 2.

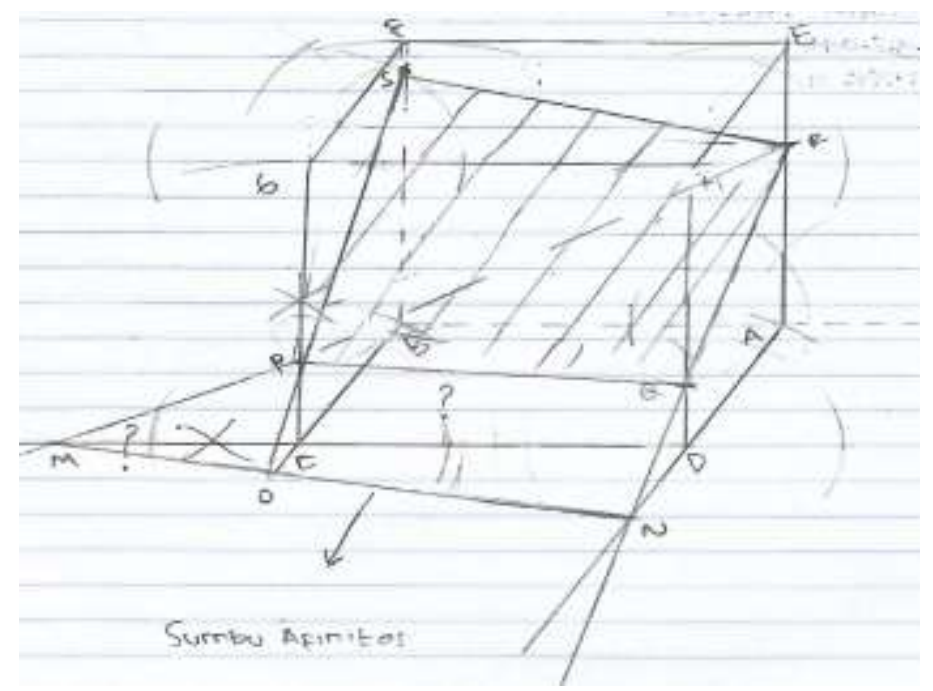

Gambar 2. Irisan Prisma yang Dibuat Subjek P

Berdasarkan gambar yang dibuat oleh subjek $\mathrm{P}$ tersebut, lalu dilanjutkan dengan wawancara yang mendalam, diperoleh informasi bahwa subjek $\mathrm{P}$ dalam menggambar terlihat tidak menghubungkan titik A dan $\mathrm{C}$ (tidak membuat garis AC). Dari wawancara dengan subjek $\mathrm{P}$ diperoleh informasi bahwa subjek $\mathrm{P}$ kurang atau tidak memperhatikan garis/segmen/bagian-bagian yang terletak pada bagian posisi horizontal pada prisma ABCD.EFGH. Hal ini dikarenakan subjek P lemah dalam kemampuan persepsi keruangan (spatial perception).

Selain itu subjek $\mathrm{P}$ membuat garis RP berpotongan dengan perpanjangan garis DC di titik M. Seharusnya Subjek $\mathrm{P}$ membuat garis AC dan membuat garis RP berpotongan di titik M. Berdasarkan wawancara dengan subjek $\mathrm{P}$ diperoleh informasi, subjek $\mathrm{P}$ hanya memperhatikan hasil kerjanya pada LTM yang menghasilkan garis RP dan DC berpotongan di titik M. Subjek P tidak menyadari bahwa garis RP dan garis DC terletak pada bidang yang berbeda, garis RP terletak pada bidang diagonal CAEG dan garis DC terletak pada bidang frontal CDHG. Sehingga perpanjang garis RP dan garis DC tidak 
akan pernah berpotongan. Subjek $\mathrm{P}$ kurang memahami bahwa dua garis akan berpotongan apabila terletak pada bidang yang sama. Subjek $\mathrm{P}$ kurang paham terhadap bagian-bagian dari bangun ruang dan hubungannya antara bagian yang satu dengan yang lainnya. Hal ini menunjukkan subjek P masih lemah dalam kemampuan relasi keruangan (spatial relations).

Selanjutnya, dalam membuat garis CB, PS dan RS, subjek P dalam gambarnya membuat garis $C B$, PS dan RS tidak putus-putus. Seharusnya segmen CB, PS dan RS dibuat putus-putus menandakan letak segmen PS dan RS berada dibagian yang tidak terlihat dari depan. Berdasarkan wawancara dengan subjek $\mathrm{P}$, hal ini disebabkan karena subjek $\mathrm{P}$ kurang dalam kemampuan membayangkan gambar tentang letak (bagian yang tidak terlihat dari depan) atau bagian-bagian yang terdapat perubahan (bagian rusuk yang tidak terlihat dari depan harus dibuat putus-putus) dari bangun ruang itu. Hal ini menunjukkan subjek $\mathrm{P}$ masih lemah dalam kemampuan visualisasi keruangan (spatial visualisation).

Terkait pembahasan di atas, maka perbedaan kemampuan spasial dapat dirangkum dalam tabel 1.

Tabel 1. Perbedaan Kemampuan Spasial Subjek L dan Subjek P

\begin{tabular}{ccc}
\hline Kemapuan Spasial & Subjek L & Subjek P \\
\hline Spatial Perception & - & Lemah \\
\hline Spatial Visualisation & Lemah & Lemah \\
\hline Mental Rotation & - & - \\
\hline Spatial Relations & - & Lemah \\
\hline Spatial Orientation & - & - \\
\hline
\end{tabular}

Berdasarkan pembahasan dan tabel 1, nampak dengan jelas bahwa mahasiswa laki-laki lebih dominan dalam menggunakan kemampuan spasialnya dalam menggambar irisan prisma. Untuk meminimalkan permasalahan kemampuan spasial, pendidik (guru/dosen) diharapkan banyak memberikan latihan-latihan terkait bangun ruang untuk mengatasi lemahnya kemampuan spasial siswa/mahasiswa yang disebabkan perbedaan gender. Hal ini sejalan dengan apa yang dikemukakan oleh Lohman (1986) dalam (Maccoby, E.E., \& Jacklin, 1974) yang menyebutkan bahwa perbedaan gender dalam kemampuan spasial ini bisa dieliminasi dengan latihan. 


\section{SIMPULAN}

Berdasarkan analisis data dan pembahasan diperoleh kesimpulan bahwa kemampuan mahasiswa calon guru matematika dengan jenis kelamin laki-laki adalah masih lemah dalam ketelitian dan daya abstraksinya khususnya dalam kemampuan visualisasi keruangan (spatial visualisation), sedangkan kemampuan mahasiswa perempuan adalah lemah dalam kemampuan persepsi keruangan (spatial perception), lemah dalam kemampuan relasi keruangan (spatial relations) dan lemah dalam kemampuan visualisasi keruangan (spatial visualisation).

\section{DAFTAR PUSTAKA}

Asis M., Arsyad N., \& Alimuddin. (2015). Profil kemampuan spasial dalam menyelesaikan masalah geometri siswa yang memiliki kecerdasan logis matematis tinggi ditinjau dari perbedaan gender. Daya Matematis: Jurnal Inovasi Pendidikan Matematika. 3(1), 1-10.

Isnaniah. (2016). Analisis spasial abilities mahasiswa program studi Pendidikan Matematika STAIN Bukittinggi. Jurnal Penelitian dan Kajian Ilmiah Menara Ilmu, 10 (1693-2617), 89-103.

Kartono. (2012). Hands on activity pada pembelajaran geometri sekolah sebagai asesmen kinerja siswa. Jurusan Matematika FMIPA UNNES.

Lohman, D. F. (1993). Spatial ability and G. Paper presented at the first spearman seminar, University of Plymouth.

Maccoby, E.E., \& Jacklin, C. N. (1974). The Psychology of sex differences. Standford: Stanford University.

Nazaruddin. (2015). Posisi gender dalam perspektif hukum Islam. Jurnal Al-Qadau, $2(2), 1-15$.

Soemadi. (1994). Pengajaran geometri di sekolah-sekolah Indonesia (satuan pemikiran alternatif). IKIP Surabaya.

Stoltz, P. G. (2000). Adversity quotient: Mengubah hambatan menjadi peluang. Jakarta: Gramedia Widiasarana Indonesia.

Susento. (2006). Mekanisme interaksi antara pengalaman kultural-matematis, proses kognitif, dan topangan dalam reivensi terbimbing. UNESA. 
Profil Kemampuan Spasial Mahasiswa....

Yilmaz, B. (2009). On the development and measurement of spatial ability. International Electronic Journal of Elementary Education, 1 (2), 1-14. 